\title{
Breve fra J. P. Junggreen.
}

III.

(Ved Hans Lund.)

\section{J. P. Junggreen til L. Jacobsen.}

25. Marts 1884. Privateje.

Det gjør sandelig heller ikke noget fornøieligt Indtryk paa mig, at man rundt om fra (thi det er skeet fra flere Steder) skriver til mig og bebrejder mig de Feil, der kunne være begaaede. - - Jeg siger ikke dette i nogen ond Mening, thi jeg veed godt, hvor godt De mener det, baade med Sagen og med mig - -, men husk dog paa, at jeg ved min Moders Død, og ved at hendes Begravelse i Flensborg fandt Sted samme Dag som Mødet, var forhindret $\mathrm{i}$ at deltage $\mathrm{i}$ dette, og derfor umulig i det enkelte kan vide, hvad der da blev aftalt. Bekker blev jo valgt til Formand for Kommitteen, har derfor faaet Ledelsen i sin Haand. ${ }^{1}$ )

Jeg har skrevet de smaa, ikke juridiske Partier af Petitiolien, dem der udtrykke vor Sorg over vort Modersmaals usle Stilling og vor Losrivelse fra Danmark. Desuden har jeg foranstaltet det fornødne for at faa den underskrevet i Aabenraa Amt. Bekker talte dog med mig om, hvormange han skulde sende til hver, og da husker jeg, at jeg udtrykkelig spurgte liam, om De ogsaa vidste Besked om det District, De skulde hesørge, hvorpaa han svarede mig, at dette var bleven aftalt naa Modet.

Jeg skrev nu straks i Formiddags til Mads Jensen i Jægerup, at han ufortøvet skulde meddele Dem, hvilken Del af Haderslev Vesteramt han og Poulsen i Bovlund besørgede, og saa maa De jo tage Resten, jeg selv har her 19 Sogne.

1) D. 13. Febr. 84 har 25 Mand efter Indliydelse af Junggreen været samlet i Aahenraa for at drofte, hvad der kan gøres "i Anledning af de usle Kaar, under hvilke vort Morlersmanal er stillet i Skolen og under Retsplejen og i alle andre offentlige Forhold«. Man heslutter at indsende en Adresse til Kultusministeriet med Anmodning om at ophave Instruksen af 9. 3 . $18 \pi \times$ og anordne en omhyggelig Undervisning i Dansk. 
Det gjør mig, som sagt, ondt, at dette er kommet saaledes, Inen De vil, ved nærmere Eftertanke, vist selv indsee, at der intet er at bebrejde mig.

Tag nu ikke ilde op, hvad jeg her har skrevet, kjare V'en, men Alverden skriver til mig, og da Ledelsen er lagt $i$ en anden Mands Haand, synes jeg dog ogsaa, at man burde henvende sig til ham.

\section{J. P. Junggreen til L. Jacobsen.}

11. April 1884. Privateje.

Jeg har jo rigtig modtaget de oversendte Petitioner, og der kommer hver Dag Masser af dem. Til nu er der rigelig 6000 Underskrifter; hvor mange der vil naaes, er vanskeligt at sige, dog vil det altid kun blive tarveligt imod, hvad vi have kunnet præstere i fordums Dage. Paa Als have Gendarmerne ikke kunnet dy sig, men have gjort Jagt paa dem - hvilket paa en Maa(le kan være heldigt nok.')

Jeg lader nu den valgte Kommittee komme sammen paa Onsdag, til hvilken Tid jeg antager, alt er indkommet. -- -

Jeg fik i Gaar de indlagte Papirer sendte fra Amorsen og sender Dem indlagt et Exemplar, hvorpaa De jo baade selv kan tegne Dem og tage imod Tegning af andre, og saa indsende det til Amorsen.

Hvad de i sin Tid omtalte Møder med Rigsdagsmændene angaar, da har jeg intet hørt om dem. Ph. Møller i Jægerup, veed jeg, har skrevet til Hans Lassen, at han maatte hellere lade være dermed, da det let kunde give Anledning til Spectakler. Johannsen havde lovet mig at afholde et Møde her i Byen, men heller ikke dette er bleven til noget. Vi have jo maaske snart Rigsdagsvalg. See saa dog, at de $i$ første Kreds kumne enes om en Kandidat. Jeg vil aldel es bestem $\mathrm{t}$ ikke opstilles. De veed selv, hvor lidt der er at udrette, og jeg har slet ingen Lyst til, tværtimod en afgjort Modbydelighed, for hele det parlamentariske Vxesen eller rettere sagt Uvæsen.

1) Adressen blev konfiskeret i 6 Sogne paa Als, hvorved der antageligt nistes ca. 400 Underskrifter (jfr. Danevirke 26. 5. 84). 


\section{J. P. Junggreen til Amorsen.}

23. April. Privateje.

Jeg har modtaget et lignende Brev som dit fra Jacobsen i Brøns, og jeg ser heller ikke nogen anden Udvej, end at I kommer sammen for at enes om Opstillingen af en Kandidat, men det forekommer mig urigtigt, at jeg skulde sammenkalde et Møde i denne Anledning. Da jeg for 3 Aar siden sammenkaldte det desværre mislykkede Møde, var Sagen en anden. At det kunde lykkes at faa valgt en dansk Rigsdagsmand i 2den Valgkreds, var der dengang ingen, der troede. Den Mand, der skulde opstilles, betragtedes som Repræsentant, ikke blot for første Kreds, men for hele Nordslesvig. Derfor var der den Gang intet urigtigt $i$, at det var en Mand fra anden Kreds, der sammenkaldte Mødet. Nu derimod er Sagen en anden. Det drejer sig udelukkende om Manden, som skal opstilles i første Kreds. Vi have jo intet andet at gøre end at se, om vi kunne faa Johannsen genvalgt. Derfor bør det ogsaa være Mænd fra 1ste Valgkreds, der tager Sagen i Haand, og naar du og Skrumsager, L. Arnum, Jacobsen fra Brøns, Reimers fra Sønderborg, og F. C. Hansen fra Løjtertoft indkalder til et Møde, er der intet $i$ Vejen for, at Folk nok skal komme. Petitionen om Sprogsagen er nu færdig og ligger hæftet her for mig. Den har faaet 8382 Underskrifter, foruden en Del gifte Koner, der har føjet deres Navn til Mændenes, - og dem, som Gendarmerne paa Als har taget, noget, der jo maa klages over paa rette Sted. Den vil blive sendt, saa snart jeg faar Johannsens Adresse. ${ }^{1}$ )

Vil du ikke, saaledes at jeg kan faa dem i Morgen (Torsdag) Aften, sende mig nogle Blanketter og Programmer om Jyllandsrejsen. $\left.{ }^{2}\right)$ Mine er alle ude, og jeg kunde bruge nogle faa endnu. Jeg kommer til Haderslev paa Fredag, men ønskede meget at have dem forinden, da jeg vel ikke kommer hjem før paa Lørdag.

1) Adressen indsendtes i Maj; den eneste Følge, den fik, var, at en Del af de Mænd, der havde samlet Underskrifter, idømtes Bøder; nogle nægtede at betale dem og fik Sagen behandlet ved Domstolene, der frikendte dem (jfr. Red. Jessen i Tale og Skrift, S. 142)..

$\left.{ }^{2}\right)$ Den store Udflugt til Vestjylland, som Konsul Amorsen ledede. 


\section{J. P. Junggreen til Skrumsager.}

21. 9. 1884. Privateje.

Efter Mødet i Vojens ${ }^{1}$ ) igaar talte jeg med Hans Lassen, Behn, Reimers og F. Hansen, Løjtertoft.

De sagde alle, at de havde været fuldstændig villig til at rette sig efter Valgkredsens nordlige Del, hvis man der havde været enig om en Kandidat, men dette havde ikke været Tilfældet. Navnlig F. Hansen opfordrede mig stærkt til nu at erklære, at jeg ikke vilde modtage Valg.

Dette har jeg personlig slet intet imod, det er kun, fordi $L$. A rnum og A morsen idag for 14 Dage siden kom til mig og fremstillede min Kandidatur som den eneste Mulighed til at samle Stemmerne paa een Mand, at jeg i det hele har indladt mig paa at opstilles, og jeg er ogsaa fuldstændig berettiget dertil, thi jeg knyttede den Betingelse til min Indvilligelse, at man skulde søge at opnaa en venskabelig Overenskomst med Alsingerne, for at vi ikke skulde have de samme Stridigheder og Spectakler som sidst. Dette er jo ikke sket, og jeg er derfor heller ikke bunden ved, hvad der afgjordes imellem Amorsen og Arnum og mig.

Jeg har, som De vil vide, aldeles ikke attraaet Posten som Rigsdagsmand; jeg har bestemt afslaaet alle Opfordringer til at lade mig opstille, indtil som ovenfor sagt de 2 ovennævnte Mænd for 14 Dage siden kom og forestillede mig min Kandidatur som det eneste, hvorom Folk vilde kunne samles. Det er derfor aldeles intet Offer for mig at træde tilbage, tværtimod, jeg vilde være glad ved at kunne gjøre det, naar Sagen er den-

1) Det kommende Rigsdagsvalg havde allerede i nogen Tid skabt en Del Drøftelser, idet Hans Lassens Edsaflæggelse havde fremkaldt et Stemningsskifte overfor ham i Haderslev Amt. 7. Sept. er en mindre Kreds af Mænd, der sidst havde staaet $i$ begge Lejre, samlet hos Konsul Amorsen i Haderslev, og det er som Udsendinge herfra, Amorsen og L. Arnum møder hos Junggreen. Det er ogsaa denne Kreds, der indbyder "samtlige dansksindede Vælgere i 1. Kreds" til et Møde i Vojens 20. Sept. - Ved dette er især Haderslev Vesteramt mødt op, nogle østfra og enkelte fra Als og Sundeved. Man vedtager, at Mindretallet skal bøje sig for Flertallet, og med stort Flertal vedtages det at opstille Junggreen. Reimers erklærer paa Alsingernes Vegne, at han intet Mandat har til at bøje sig for dette Mødes Afgørelse. Stemningen hos dem er saadan, at man kun er rede til at bøje sig for et enigt Haderslev Amt. 
ne, og dette Sporgsmaal tillader jeg mig herved at rette til Dem.

Tror De, at Stemningen i Haderslev Amt er en saadan, at jeg ved at træde tilbage kan tilvejebringe Enighed, saa at Folket stemmer paa H. Lassen? Eller maa jeg befrygte, at det gaar ligesom sidst, at en Del Vælgere dog stemme imod ham, og at der saaledes, ved et saadant Skridt fra min Side, kun afstedkommes endnu større Forvirring. ${ }^{2}$ )

Jeg henvender mig til Dem, fordi vi jo aldrig have staaet hinanden saa nær, at jeg kan befrygte, at personlig Forkjærlighed for mig kan gjøre, at De saae Forhodlene $i$ et andet Lys end det virkelige, og fordi det ved en saadan Lejlighed netop kommer an paa at faa et Svar, der ikke er paavirket af en saakommes enduu større Forvirring. ${ }^{1}$ )

\section{J. P. Junggreen til Skrumsager.}

24. 9. 1884. Privateje.

Jeg takker Dem for Deres Brev, og jeg vil saa foreløbig se Tiden an. Vi faar jo saa se, hvorledes Tingene udvikler sig.

Det var dog om en anden Ting, jeg vilde skrive i Aften. Jeg ved ikke, hvor talrige Tyskerne ere i Rødding og Omegn, om der er nok af dem til at gøre Spektakler. - Jeg ved ikke, om De husker et Møde, som P. Skau en Gang havde indvarslet i Haderslev. Der gik det saaledes, at Tyskerne vare kommen først og havde besat de fleste Pladser i Lokalet, saa at Skau, for ikke at faa det modsatte Resultat end det, der var tilsigtet, ud af Mødet, straks maatte have det, til stor Moro for Tyskerne. -- Jeg ved som sagt ikke, om der er saa mange Tyskere i Rødding og Omegn, at noget lignende kunde sattes i Scene der, men har dog villet henlede Deres Opmærksomhed paa, hvad der skete ved hint Mode i Haderslev, for at De, hvis der kan være Fare for noget lignende, kan sørge for, at danske Folk møde $\mathrm{t}$ a l rig t og i Ti d e. Vi have jo indbudt offentlig; der kan altsaa komme, hvem der vil, og kunde Embedsmændene og de-

1) Skrumsager indrommer i Brev af 23. 9., at J. nu var berettiget til at træde tilbage, men han heder ham ikke forhaste sig: der er dem, der under ingen Omstrendigheder vil stemme paa Lassen - det viste sig i Vojens. 
res Tilhængere spille os et Puds, vilde det naturligvis være dem en stor Glæde.

Det er jo muligt, at der slet ikke kan være Tale om sligt hos Dem, men Forsigtighed er, som De ved, en Borgmesterdyd, og da Tingell er faldet mig ind, har jeg ikke villet undlade at henlede Deres Opmærksomhed derpaa. - Folk behøve ikke at være bange for at høre paa mit Foredrag. Jeg skal nok sige, hvad jeg vil paa en saadan Maade, at ingen skal kunne gjøre os noget derfor.

\section{J. P. Junggreen til Gustav Johannsen.}

16. 10. 1884. R. A.

- - Det er sørgeligt med dette Valg i første Kreds. Der kommer vi rimeligvis igen til at stemme paa os begge. $\left.{ }^{1}\right) \mathrm{Jeg}$ har ikke tilstrækkelig Indflydelse paa Folket i Haderslev til, at jeg kan faa dem til at stemme paa Hans Lassen; jeg har forsøgt alt muligt $\mathrm{i}$ den Retning, hvorimod jeg tror, at naar Lassen vilde, kunde han faa Alsingerne til at opgive deres Modstand. Men det er jo muligt, at jeg tager Fejl deri. Sorgeligt er det i al Fald, at vi ikke kunne enes, selv under saa fortvivlede Forhold som de nuværende, da der hviler et Tryk paa os som aldrig tilforn.

\section{J. P. Junggreen til Gustav Johannsen.}

1. 11. 1884.

Jeg har idag skrevet en lille Art. i Fl. A., som jeg ligefrem maa bede dig om ikke at misforstaa. Folk her, baade i Byen og paa Landet, har været saa gruelig forknytte, fordi du ikke blev

1) Der er $\mathrm{i}$ den mellemliggende Tid bleven gjort flere Forsgg paa at tilvejelringe Enighed, men forgæves. 12. 10. opfordrer Skrumsager offentligt til at stemme paa Junggreen. 15. 10. samles en Del Mænd fra $\emptyset$ steramtet (P. Skau, Sabroe, J. P. Friis o. fl.) og opfordrer til at stemme paa Hans Lassen. 1\%, 10. samles Alsingerne og fastholiler Hans Lassens Kandidatur.

Ved Valget 28. 10. 1884 faldt Stemmerne saaledes:

\begin{tabular}{rrrrrr} 
Haderslev Amt: & Junggreen & 4159 & Lassen & 870 \\
Sønderhorg Amt: & Junggreen & 157 & Lassen & 3191 \\
\hline Ialt: & Junggreen & 4316 & Lassen & 4061
\end{tabular}

Tyskeren Bachmann fik 2765. Der skal derefter være Omvalg mellem de to clanske Kandidater. Det flnder Sted d. 11. Nov. - Hans Lassen har forinden meddelt, at han trokker sig tilbage for Junggreen. Der afgives saa ved Valget 6891 St. for Junggreen og 213 for Lassen. 
valgt, $\left.{ }^{1}\right)$ at jeg har anset det for min Pligt at vende den lyse Side af Sagen frem, for at ikke dette Nederlag skal have altfor slemme Følger for os. Jeg er selv dybt bedrøvet over, at det er gaaet saaledes. Min Stilling i Rigsdagen bliver jo yderst vanskelig, naar jeg er der ganske alene ubekjendt med alle Forhold og med det parlamentariske Væsen i Alm. - - Foreløbig maa vi jo lade Tingene gaa som de kunne, men saa anser jeg det for absolut nødv., at vi komme sammen, en Snes Mennesker, for at reconstruere vort Parti paa et Grundlag, der udelukker Stridigheder af den Slags, der er ført $i$ de sidste 3 Aar. Blive vi saaledes ved, ødelægge vi selv vor gode Sag. - Ja, kjæreste Ven, find dig nu i din Skjæbne det bedste du kan. Gud give, at det var dig, der var bleven valgt i Stedet for mig.

Junggreen til P. A. Madvig.

16. 11. 1884. R. A.

- - - Gud give mig nu Kraft og Evne og Lykke til at repræsentere vort Folk, saaledes som det skulde repræsenteres. - Ingen af mine Forgængere er jo saaledes første Gang kommet derned alene, og uden forhen at have deltaget i parlamentariske Forsamlinger. Jeg maa jo nu see at orientere mig lidt $i$ Situationen og i Maaden, hvorpaa der kan gaaes frem. Jeg har jo intet Parti at slutte mig til, det skulde da være Polakkerne eller Elsass Lothringerne, men derom kan jeg jo forst danne mig en Mening, naar jeg har været der i nogen Tid. Hvis jeg kunde udfylde Pladsen, saaledes som jeg ønsker at gjøre det, da var den godt besat, men om Evnen svarer til Viljen, det kan kun Tiden vise.

\section{Junggreen til P. A. Madvig.}

9. 12. 1884. R. At

- - - - Hvis De og vore Venner ere tilfredse med mit Arbejde her i Rigsdagen, ${ }^{2}$ ) er jeg glad derfor. Mig selv forekommer det kun ubetydeligt. Jeg kunde vel have faaet Ordet tiere, men man maa ikke komme med sligt hveranden Dag, da det

1) Landretsraad Gottburgsen havde ved Valget faaet 6617 St. mod Gustav Johannsens 4926 St. og Socialdemokratens 920.

$\left.{ }^{2}\right)$ Junggreen har 28. 11. talt mod Militærbudgettets Forøgelse og taget Anledning til at minde om Art. 5. 
saa ingen Virkning gjør og kun giver Anledning til haanlige Bemærkninger. Imorgen kommer rimeligvis Polakkernes Sprogandragende for, og det er muligt, at jeg da tager Ordet, dog saa ikke for at tale om vor Sag (jeg maa jo spare mine Argumenter til mit eget Andragende), men for maaske at gjøre dem lidt Gjengæld for den Hjælp, de have ydet mig.

Der er forresten kjedeligt for mig her $i$ Berlin. Polakkerne og Elsasserne lade kun et Par af deres Medlemmer blive her. Resten er stadig hjemme og kommer kun, naar der finder en Afstemning Sted, som de onske at tage Del i. - - Med enkelte af de andre Rigsdagsmænd taler jeg ganske vist en Gang imellem, dog er dette kun undtagelsesvis. - Maaske kan det jo blive lidt mere med Tiden.

\section{J. P. Junggreen til L. Jacobsen.}

2. Juledag 1884. Privateje.

Tak for Deres Brev. Det er naturligvis en Glæde for mig at see, at mine Venner er tilfredse med, hvad jeg foretager mig $i$ Berlin. At jeg har den bedste Vilje til at gjøre alt saa godt, jeg formaar det, derom tvivler De jo ikke, men derfor er det ikke altid sikkert, at min Optræden vil svare til, hvad De vilde gjøre, hvis det var Dem, der var hernede. Ethvert Menneske har jo sin egen Maade at være paa og kan kun tale ud af sin egen Individualitet, og jeg troer ogsaa kun netop derved paavirke andre, at han virkelig viser sig at være en Individualitet, og ikke kun en blot og bar Gjennemsnitsprøve af den store Mængde. Skulde jeg derfor en Gang træde anderledes op, end De vilde gjøre det, saa kjære Ven, døm ikke for strengt derom, men vær overbevist om, at jeg har gjort, hvad der efter min Overbevisning var det rigtige, og hvad mine Evner satte mig istand til at udrette. Den 7. Januar reiser jeg igjen til Berlin. Da jeg er ganske alene der, kan jeg jo ikke som de fleste andre Rigsdagsmænd tage mig det mageligt, men maa være der, for at gribe Ordet, naar det gjøres Behov, og naar der er Lejlighed dertil, hvad der jo forresten tidt ikke er, netop naar man mest ønskede det. Gid nu alt maa forme sig godt for vor Sag i det nye Aar, men gid fremfor alt Bestræbelserne for $\mathrm{h}$ e $\mathrm{r} \mathrm{h} \mathrm{j}$ e $\mathrm{m} \mathrm{m}$ e at værne 
om vort Modersmaal og det danske Sindelag maa blive fortsatte med fuld Kraft. Paa disse 2 Ting, Modersmaalet og det danske Sindelag, beroer dog i sidste Instants Muligheden for vor Frelse. ${ }^{1}$ )

\section{J. P. Junggreen til Skrumsager.}

4. 1. 1885. Privateje.

Tak for dit Brev og Tak for Bøgerne. Det er tilvisse gorle Ting, Frk. Rosenørn skriver, $\left.{ }^{2}\right)$ og det undrer mig, at disse Digte ikke ere komne i Boghandelen. De staar dog uendelig højt over meget af det, der ellers kommer frem. Jeg tager dem med til Berlin. Det er godt, naar man saaledes Dag ud og Dag ind lever i fremmede Omgivelser, en Gang at kunne læse et af disse saa agte danske, og dog i mange Henseender saa ejendommelige Digte. Maa jeg bede dig bringe Frk. Rosenørn min Tak, naar du skriver til hende. - Det glæder mig naturligvis, at du og mine Vælgere have været tilfredse med, hvad jeg har udrettet $\mathrm{i}$ Berlin. Store Ting har det jo ikke været, men der er i Virkeligheden ikke meget mere at gjøre end lejlighedsvis at soge at faa Ordet, og saa, saa godt som muligt, at sige dem den rene Sandhed. - Den skulle de faa at hore fra min Mund, saa ofte jeg kan faa Lejlighed.

Jeg haaber, at en saadan skal byde sig for mig, naar jeg, hivad jeg antager vil ske snart, skal begrunde mit Lovforslag. ${ }^{3}$ ) Med dette har jeg dog begaaet en Forseelse ved ogsaa at omtale Administrationssproget, der ligger uden for Rigsdagens Kompetence. Sligt kan jo nok passere, naar man forste Gang deltager i en stor parlamentarisk Forsamling, og under saa forviklede Forfatningsforhold, hvor Ting af ganske samme Natur

1) Junggreens Taler i Rigsdagen - han har bl. a. talt i Anledning af Polakkermes Sprogpropaganda, - vakker megen Glade i hans Hjemstavn. En af dem, der overfor ham giver Udtryk herfor, er Cornelius Appel. Hans Brev til Junggreen er trykt i "Hejmdal « 13. 8. 1927.

$\left.{ }^{2}\right)$ Frk. Ingehorg Christiane Rosenørn-Teilmann $(1852-1929)$ til Stamhuset Norholm vel Varde skrev forskellige historiske og lyriske Arbejller. Hun stod gennem en længere Aarrække i Brevveksling med J. N. H. Skrumsager.

3) Junggreen indlbragte i Rigsdagen i Jan. 85 et Forslag om Forvaltnings- og Retssproget i de til Riget hørende Landsdele, i hvilket et ikke-tysk Sprog er Folkesproget. Det behandledes forste Gang $2 x$. Januar. 
ikke kunne behandles $i$ den samme Forsamling. Jeg maa straks erklære, at jeg lader den Del af mit Forslag, der omhandler Administrationssproget, falle, og ville de, kumne de saa endda forhindre mit Forslag i at nyde Fremme. Jeg tror dog ikke, de gjore det. Skeer det, saa stiller jeg straks et andet, der er rigtigt i Formen, men det vil saa ikke komme til Forhandling før i Sommer- eller Efteraarssamlingen. -

Arbejder I andre nu her hjemme paa alle mulige Maader for at opretholde Sproget og det danske Sindelag hos Folket. Det er og bliver Hovedsagen. Skriv du, kjære Skrumsager, en Gang imellem et Stykke i Bladet. Du er en af dem, der kan, og vi træenge til det. Det var godt, om der kunde oprettes flere Foreninger som den, Ph. Møller har faaet oprettet, $\left.{ }^{1}\right)$ hvor den menige Befolkning (jeg mener dermed den Del, der trænger haardest til at faa tilført aandelig Næring udefra) kunde blive paavirket med det $\mathrm{m} u \mathrm{u}$ d $\mathrm{t} \mathbf{l} \mathrm{g}$ e Ord. Det var jo, som du ved, min Mening at have optaget en saadan Gjerning, men naar jeg nu skal ligge tredie Delen af Aaret i Berlin, kan dette kun ske efter en meget indskrænket Maalestok, thi jeg har intet andet at leve af og ernære min Familie med end min Forretning, og denne stiller saa store Krav til mit Arbejde i de Mellemrum, hvor jeg kan være hjemme. Det var derfor godt, om andre nu vilde tænke paa denne Sag.

Nu Farvel for denne Gang. Tirsdag Aften rejser jeg til Flensborg for at tale med Monrad om Sprogforeningens Anliggender, og saa Onsdag Morgen til Berlin.

Gud give mig Lykke til min Gjerning, og han hjælpe snart vort stakkels Folk.

\section{J. P. Junggreen til Gustav Johannsen.}

16. 1. 1885. R. A.

$\mathrm{Nu}$ er jo Gottburgsens Valg kasseret. ${ }^{2}$ ) Jeg har ikke blandet mig i Forhandlingerne derom, fordi jeg oprigtig talt hellere

1) Philip Moller fik stiftet Nordslesvigs første Foredraqsforening, "Foredragsforeningen for Nustrup med flere Sogne«, ved et Møde i Vojens, Dec. $18 \times 4$.

2) Forst i 1886 fandt Omvalget Sted, og Gotthurgsen genvalgtes. 
havde set, at det var blevet godkendt. Jeg har ikke noget overdrevent stort Haab om, at vi kunne sætte Valg igennem i 2. Valgkreds, og det havde været nok, om det var kommet igen efter Valgperiodens regelmæssige Forløb.

$\mathrm{Nu}$ er det jo imidlertid saa, og nu maa der gøres de $\mathrm{s}$ t ø $\mathrm{r}$ s te Anstrengelser for, om muligt, at sætte dit Valg igennem. Jeg kan ikke komme hjem nu. I Dag fortsætter Debatten om Udvisningerne, og jeg har meldt mig til Ordet. Om jeg faar det, ved jeg naturligvis ikke. - - -

Dine frisindede Venner er glade over Muligheden af atter at faa dig herned, men deres Venskab er kun af liden Nytte; thi naar det kommer til det yderste, tør de dog ikke støtte dig. Centrum har mere Courage. Det er ikke bange for at støtte Polakkerne. - - -

\section{J. P. Junggreen til Hiort-Lorenzen.}

6. 2. 1885 . K. B.

Jeg takker Dem meget for Deres venlige Brev. Det er jo altid glædeligt at se, at Folk er tilfredse med, hvad man har gjort. Jeg var det dog ikke selv, var tvertimod ligefrem forknyt, da Forhandlingen var forbi, fordi jeg syntes, at jeg ikke havde svaret de Herrer, der talte imod mig, godt nok. $\left.{ }^{1}\right)$ - Det er naturligvis vanskeligt, naar man angribes af 6 forskellige Talere, saa øjeblikkeligt at skulle sammenfatte alt, hvad der skal siges til Gjensvar, og bagefter falder der een mange Ting ind, som man burde have sagt. -

\section{J. P. Junggreen til Villars Lunn.}

11. 2. 1885. Privateje.

Idag for 14 Dage siden kom jo mit Andragende om Retssproget til Forhandling, og jeg havde en lang og varm Debat med en hel Mængde Modstandere. Derom har I jo nok læst i Bladene. Jeg selv var langt fra at være tilfreds med, hvad jeg havde præsteret, men Folk rundt om synes jo at være det, og saa maa det jo hjælpe sig. Mine Modstandere burde efter min

1) Der hentydes til Forhandlingerne om det før nævnte Forslag. - Hiort-Lorenzen har bl. a. skrevet (Brev 3. 2. 85), at den Tale, J. ved den Lejlighed har holdt, wafgjort er den bedste Tale, der endnu er holdt af nogen Dansk paa det Sted". 
Mening have haft ganske anderledes Svar, end de fik, men det er vanskeligt, naar man saaledes skal svare 6 Angribere paa een Gang og øjeblikkeligt, da at faa alting med. Nu, Resten skulle de faa en anden Gang. - - -

[Skildrer Iveren for Beskyttelsestolden. Rigsdagen a r b e jd e r.]

En Rigsdag som Eders, der intet bestiller, vilde snart blive furet af det tyske Folk, der, hvad man end kan have imod det, er et patriotisk og et dygtigt Folk.

\section{J. P. Junggreen til Hiort-Lorenzen.}

8. 5. 1885. K. B.

- - Jeg har været hjemme en 8 Dages Tid. Om jeg faar Lejlighed til endnu engang at omtale den nationale Sag, er meget tvivlsomt. Vi forhandle hver Dag om Toldsagen og om andre Ting, ved hvilke der aldeles ingen Lejlighed er dertil. - og Rigsdagen vil snart blive sluttet, hvad jeg er overordentlig glad ved, da her er meget kjedeligt, og jeg trænger $h$ a a $r d t$ til at komme hjem og se til mine egne Sager. -

Om jeg forresten faar Lov at blive længe hjemme, er uvist. Jeg er anklaget for en Artikel, jeg i Efteraaret skrev om Udvisningerne, og maaske gaar jeg fra Rigsdagen, efter et kort Ophold hjemme, i Fængsel. ${ }^{1}$ ) Dette maa jo imidlertid gaa, som det kan. Jeg hører kun lidt om Forholdene i Danmark. Gid det maatte bedre sig og gaa godt.

\section{J. P. Junggreen til Skrumsager.}

2. 6. 1885. Privateje.

Fredagen den 5. ds. kommer den prøjsiske Kultusminister her til Byen for at inspicere Seminariet og Skolerne her og i Omegnen. Han burde ikke gaa herfra, uden at vore Klager over den Maade, hvorpaa vort Sprog behandles i Skolen, ere blevne ham forebragte; det vil ellers hedde, at ingen har klaget, og at Folket er fuldstændig tilfreds med de bestaaende Tilstande.

Jeg med flere har derfor tænkt, at en Deputation burde søge Audiens hos Ministeren og forebringe ham vore Klager. Af den-

1) Junggreen blev ikke dømt. 
ne Deputation beder jeg Dem at være Medlem, og i den Anledning at møde her i Haderslev hos Hr. Bøllemose Fredag Formiddag Kl. 9.

Jeg beder Dem meget om at komme.

\section{J. P. Junggreen til Skrumsager.}

18. 6. 1885. Privateje.

- - See om du ikke kan faa nogle Folk til at møde paa Sprogforeningens Generalforsamling. Netop i denne Tid, hvor de lyve om os paa det grueligste og fortælle, at nu er det snart forbi med os, burde den dog være nogenlunde besøgt.

\section{J. P. Junggreen til P. A. Madvig. $\quad$ 8. 9. 1885. R. A.}

Det har gjort et yderligt nedslaaende Indtryk paa mig at høre, at De og Deres Venner mene, at vi ikke kunne holde Møde i Haderslev uden at udstede Adgangskort. Det forekommer mig at være en saa stor Indrønmelse ligeoverfor Tyskerne, at jeg, hvis dette ikke kan undgaas, anseer det for heldigere slet intet Møde at holde i Byen.

Det vilde være mig særdeles kjært, om jeg een af Dagene kunde samles med Dem, Amorsen, Sabro, et Par andre gode Mænd fra Byen, og desuden Ph. Møller, P. Skau, H. J. Jensen fra Bæk og enkelte andre gode Mænd fra Østeramtet, som De jo bedre kjender end jeg, for at drøfte denne Sag. Det forekommer mig, at hvis de rette Forholdsregler tages, maatte der kunne holdes et dansk Møde i Haderslev, uden at vi behøve at ty til den Forholdsregel at udstede Adgangskort.

Skulle De kunne foranstalte en saadan Sammenkomst af nogle faa Mænd, vel helst $i$ et Privathus, og vilde De gjøre mig Meddelelse om Dagen og Timen, da skal jeg give Møde og vilde være Dem meget forbunden.

\section{J. P. Junggreen til Hans Lassen.}

12/9 1885. Privateje.

Indlagte Opfordring ${ }^{1}$ ) er, som du vil se af Skaus Brev, sendt mig med Bøn om at sende det til nogle flere gode Mænd

1) Opfordringen drejer sig om Stotte til de danske Efterskoler i Hejls, Skibelund og Lustrupholm, for at de kan modtage sønderjyske Elever paa billige Vilkår. 
hernede. Jeg sender det nu til dig og har, som du ser, tilføjet min Underskrift. Jeg beder dig nu gjøre det samme, ogsaa maaske lade een eller anden god Mand af dit Bekjendtskab underskrive, og derpaa sende den til Knudsen paa Trøjborg, hvis han saa selv vil underskrive og maaske bevæge een af de mere fremtrædende Mænd i sin Egn dertil, saa mener jeg, at det kunde være tilstrækkeligt. Han kunde saa sende den direkte til P. Skau; at sende den tilbage til mig, er jo kun Tidsspild. -

Jeg kommer jo saa en Gang først i Oktober til Als, og du og jeg kunde jo saa vise Folket, at vi ere Venner, der begge med de Evner, vi have, virke for en god Sag. Det maa lære at indse Nødvendigheden af at holde sammen, og at vi, om vi ikke kunme enes om en enkelt Ting, derfor ikke forkætre hinanden, men lade den Sten ligge, som vi ikke kunne løfte, og i alt andet trofast støtte hinanden.

\section{J. P. Junggreen til Villars Lunn.}

6/12 1885. Privateje.

- - Det er en overordentlig kedelig Stilling at være i Berlin, saa ene som jeg er, og er det mig muligt at slippe derfor, saa vil jeg ikke mere vælges dertil dog med Undtagelse af, at Rigsdagen nu bliver opløst. Saa vil jeg tage mod Valget for ikke at bringe Forvirring ind $i$ den danske Befolknings Rækker. - Men ellers vil jeg gjøre alt for at slippe ud af en Stilling, der er mig i højeste Grad modbydelig. Paa enhver anden Maade. ved at skrive, eller holde Foredrag for dem, er jeg villig til at arbejde for mit Folk, men jeg vil ikke tilbringe Halvdelen af den Rest af mit Liv, der endnu er tilbage, under Forhold, der er mig saa ubehagelige. - - -

\section{J. P. Junggreen til P. A. Madvig.}

21/12 1885. R. A.

Jeg har jo lovet det, og derfor sender jeg Dem vedlagte Adresser paa Rigsdagsmænd. Jeg er dog bedrøvet over dette hele Fortagende, ${ }^{1}$ ) da jeg er overbevist om, at det enten slet ingen Virkning vil have, eller kun en skadelig. Brochurens Indliold er jo, hvad jeg enten har sagt, eller lidt efter lidt vil

1) Det drejer sig om en Pjece med Uddrag af Junggreens Taler. 
komme til at sige, i Rigsdagen. Saa maa de Herrer da have noget at sige derimod, ja træde offentlig frem, og saa kan jeg igjen tage til Gjenmæle. En saadan Brochure derimod vil jo, hvis den overhovedet bliver læst af Venner og Bekjendte, ogsaa blive vist til de Herrer Francke, Gottburgsen, Hänel \& Consorter, der fo ogsaa nok skulle sørge for at give Oplysninger og Redegørelser for deres Standpunkt, som saa ingen faar Lejlighed til at berigtige.

Jeg anser det for et Fejlgreb at udbrede sligt, og for en Illusion, naar man troer at kunne udrette noget paa den Maade.

Hvad der kan udrettes ved mundtlig Samtale med dem, jeg anser det for muligt at paavirke, og ved ligefrem at sige Sandheden fra Talerstolen, det gjør jeg saa godt jeg kan, og kan der ikke udrettes noget paa den Maade, saa langt mindre paa nogen anden. Jeg sender Dem disse Adresser, fordi jeg har lovet det, men er slet ikke glad for den Sag. - - -

\section{J. P. Junggreen til C. Amorsen.}

14/2 1886. Privateje.

Vedlagt sender jeg dig Kvittering for de $800 \mathrm{Mk}^{1}$ ) - Det gjør mig ondt, at De har maattet skyde Penge for; det var jo paa ingen Maade min Mening, og jeg kunde godt have hjulpet mig med, hvad der var kommet ind. Sagen er kun, at jeg nu om 8 Dage skal bruge over 10,000 Mk., og derfor ønskede at faa, hvad jeg har lagt ud.

See nu først til, at du faar dine udlagte Penge. Hvad jeg saa skal have mere, kan jeg jo faa senere. Jeg har desværre ikke været rask $\mathrm{i}$ den senere Tid, og da jeg havde den sidste store Debat overstaaet, tog jeg derfor Orlov i 14 Dage for at see, om et Ophold i Hjemmet ikke skulde kunne hjælpe mig lidt. Jeg har nu været hjemme i 8 Dage og kan jo blive en Uge endnu, saa haaber jeg, at jeg atter kan rejse derned.

1) Der ydedes af de danske Vælgere økonomisk Støtte til Rigsdagsmanden. Pengene indkom ved Indsamling. 
Jeg skulde gjerne, thi mit Andragende') kommer jo endnu til 2. Behandling, og er der ingen Udsigt til at faa det vedtaget, saa kan jeg dog faa Ordet for at sige dem, hvad jeg ikke fik sagt forleden.

Man faar aldrig alt med den første Gang. Man kan jo ikke vide al Ting, og bagefter falder der een altid en hel Del ind, der burde have været sagt. Saaledes gaar det imidlertid ogsaa alle andre. Kan jeg nu komme derned, saa kan der endnu en Gang komme en Debat i Gang derom. Det glæder jo dog Folk herhjemme at læse det og gjør ogsaa lidt Gavn dernede.

De store berlinske Blade nævne dog nu ogsaa altid "die Dänen«, naar de taler om Rigsfjenderne i Rigsdagen, og forleden læste jeg i et af dem, at skulde der nogensinde igjen blive Tale om at annectere Land som Elsass eller "Nordschleswig" saa vilde de bestemt mod'sætte sig det. Af den Slags havde de nok.

\section{J. P. Junggreen til C. F. Monrad.}

17/2 1886. Privateje.

Jeg har faaet den tyske Udgave af Allens Sproghistorie af Mørk-Hansen og kan beholde den foreløbig. Jeg maa vel, og kan ogsaa godt, hjælpe mig med de Oplysninger, denne indeholder.

L. Skaus Skrift om P. H. Lorenzen fik jeg idag tilsendt fra P. Skau, men det indeholder saa godt som intet om den omhandlede Sag, dog noget om Nis Lorenzens Anstrengelser for at faa indført dansk Retssprog. Jeg troede, at der existerede en Biografi af Nis Lorenzen, der jo saa vilde have indeholdt speciellere Oplysninger. Jeg har dog nok i, hvad der findes hos Allen, og De skal ikke gjøre Dem videre Ulejlighed.

Det har været daarligere med mig, men det er dog nu bedre, og det er min Hensigt at rejse til Berlin paa Mandag. Faaer De intet Brev forinden, kan De bestemt vente mig denne Dags Form. 91/2, og det vilde glæde mig at tale med Dem. Igaar var

1) Junggreen har i Jan. 86 indbragt et Lovforslag om Ligeberettigelse af det danske og det tyske Sprog som Retssprog $i$ Nordslesvig. Det kom til 2. Behandling i April. 
Rosendal fra Vinding her og skulde holde et Foredrag for Landboforeningen (om Henrik Ibsen vilde han have talt) men det blev ham forbudt af Politimesteren. Det er jo et nyt Tryk, der lægges paa os, men jeg sørger ikke saa meget derover. Jeg har lovet selv senere at holde nogle Foredrag, og der er ogsaa andre, der baade kan og vil. Michelsen i Kolstrup holdt paa staaende Fod et ganske godt Foredrag om Grundstofferne, saa Hensigten, at faa Mødet ødelagt, blev ikke naaet. Det er i det hele ingen Skade, om vi blive nødt til i denne Heseende at tage fat selv.

\section{J. P. Junggreen til P. A. Madvig.}

22/4 1886. $\left.{ }^{1}\right) \quad$ R. A.

- - Hvordan det er gaaet mig i Berlin, har De jo set. Jeg har gjort mit bedste, men det er jo umuligt at opnaa noget positivt Resultat. Flertallet er hovmodigt og blændet af Rigets Storhed og Magt, der efter dets Mening tillader, at man sætter sig ud over alle Hensyn, og et Mindretal har ikke Courage til at vedkende sig dette. De bliver jo saa straks henregnede til Landsforræderne og Rigsfjenderne. De eneste Tyskere, der ved Afstemningen ærligt har vedkjendte sig deres Mening om, at der er og bliver gjort Uret imod os, er Socialisterne.

Om jeg rejser ned til Berlin igjen, naar Samlingen begynder den 17. Maj, veed jeg endnu ikke. Om den nationale Sag kan jeg nu ikke tale mere i denne Session. _ - -

J. P. Junggreen til Villars Lunn.

30/5 1886. Privateje.

- - Jeg har kun haft det daarligt i denne Vinter og $\mathbf{i}$ Foraaret. Der har været Tider, da jeg troede, at jeg skulde dø, og saa er man kun lidet oplagt til at skrive. Nu er det dog noget bedre, og jeg tror, at jeg kommer over det denne Gang. - -

$\mathrm{Nu}$ efter Pintse vil jeg dog igjen ned til Berlin. Der er vigtige Sager til Forhandling, og jeg antager ikke, at det vil vare ret længe. I den korte Sammenkomst efter Paaske har

1) Brevet indledes med en Skildring af Junggreens Sygdom, der i den sidste Tid har forværret sig. 
jeg ikke deltaget. Det var om en Omordning af Sukkerbeskatningen og om en ny Brændevinsskat, der forhandledes. [Det sidste i Udvalg, det første har han ingen Indsigt i.] Heller ikke er det jo disse Ting, der ligger mig og mine Vælgere særligt paa Sinde, og den nationale Sag vil jeg ikke mere bringe paa Tale i demne Session. Jeg har talt mange Gange om den, og man maa ikke komme alt for tit dermed. Naar jeg nu alligevel rejser derned efter Pintse, saa sker det for at stemme for, eller hvis ingen anden gjør det, selv at stille et Andringsforslag til Brændevinsskatteloven, gaaende ud paa, at samtidig med dens Ikræfttræden skulde nogle andre Skatter paa uundværlige Livsfornødenheder falde bort. Jeg tænker nærmest paa Salt, Kaffe og Petroleum, da disse Artikler jo staa ganske udenfor Spørgsmaalet om Frihandel eller Beskyttelsestold...

\section{J. P. Junggreen til P. A. Madvig.}

17/6 1886. R. A.

Om jeg i det hele tiere kommer til at tale vor Sag i Berlin, er uvist. Der er Dage, hvor jeg synes, jeg maa kunne det, men ler er andre, hvor det forekommer mig, at jeg ikke mere vil være istand dertil. - - - Hvorledes det end bliver dermed, saa ønskede jeg dog endnu engang at tale til Folket herhjemne, og jeg har derfor tænkt, at jeg ligesom ifjor vilde afholde nogle Møder. - - Der er nok at tale om. Foruden at omtale, hvad jeg har søgt at udrette for vore Folkesag, kan der jo ogsaa tales om den politiske Stilling i Almindelighed, om Rigskanslerens Skatteprojekter og om de Nederlag, han har lidt i denne Henseende. Ogsaa de polske Affærer og Canossagangen kan jo omtales. - - - Jeg har tænkt paa dette, især da vi jo ingen Generalforsaming kan faa i Sprogforeningen, og det dog vel vil glæde Folk at komme sammen.')

1) Der planlargges Møler til sirlst i Juli Maaned, men ret pludseligt forværredes Junggreens Sygdom, og den 19. Juli døde han. 